
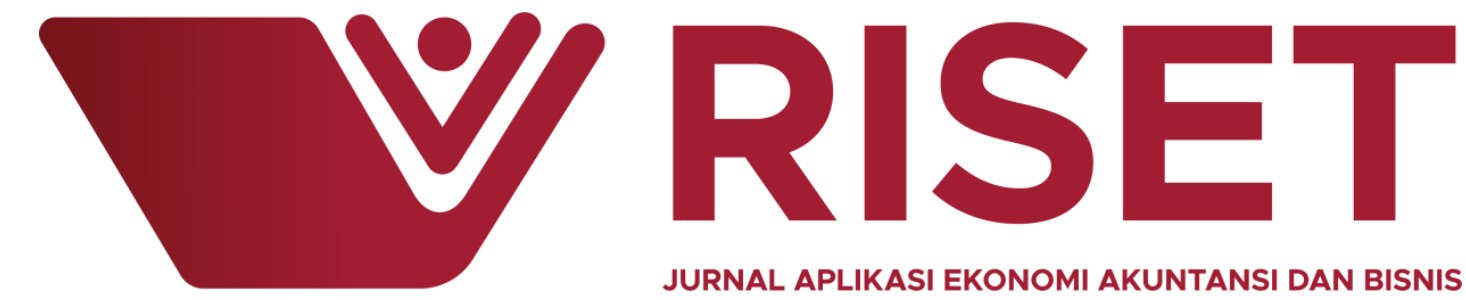

JURNAL APLIKASI EKONOMI AKUNTANSI DAN BISNIS

\title{
Share Investors' Competence and Overconfidence in Investment Decision Making
}

Deasy Lestary Kusnandar ${ }^{1)}$, Agi Rosyadi ${ }^{2}$,Lucky Radi Rinandiyana ${ }^{3)}$

123) Siliwangi University

INFO ARTIKEL

\begin{abstract}
In making investment decisions, many things can affect an investor; among others, are investor's competence and confidence. This study aims to measure the effectiveness of an investor's competence and overconfidence in making investment decisions. The sample measurements were carried out by judgment sampling of 30 respondents of novice investors. The analytical tool in this study is the multiple regression analysis. The results of the study show that competence does not affect investors in investment decisions, while investment decisions are influenced by an investor's overconfidence.
\end{abstract}

Share

Investors' Competence and Overconfidence in Investment Decision Making

Submitted:

22 - Juli - 2019

Revised:

19 - September - 2019

Accepted:

21 - September - 2019

Keywords: competence, confidence, investment decisions

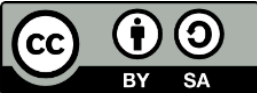

E-mail: deasylestary@unsil.ac.id

\section{INTRODUCTION}

In the last three decades, the discipline of finance has developed rapidly by holding on to the assumption that investors make decisions in a rational manner (Frinjs, et al., 2008). In practice, it turns out this does not always apply. The assumptions held in modern financial theory are considered by many economists-psychologists as a bad assumption(Nofsinger, 2005) .

A strong impression has been formed that the traditional financial theory (traditional finance), which assumes that rational decisions are made empirically been proven. However, in line with the changing times in various fields, especially on investors' understanding of an investment, the investment world has begun to experience a paradigm shift. The awareness of the role of behavior as a major factor in determining a type of investment began to emerge.

(Gumanti, 2009) suggested that financial behavior emphasizes the explanation and comprehension (understanding), including the patterns of investors' behavior as psychological-emotional processes that influence investment decisions. The field presents an integral catalyst of sociology, psychology, and finance 
(Nofsinger, 2005) argues that some professionals in the realm of economics view realistically that an investment decision can result from an irrational process. Psychological aspects of investors contribute to affect the investment decisions made. In addition, they argue that investment decisions are made as a result of social interaction from the environment, relatives, and so on, so that the potential for social influence may be a factor in influencing investors.

In line with the development of thinking, slowly the financial sector that is driven by bad assumptions, it is starting to realize that bias in an economic decision will be possible. Even anomalies that occur in the field raise questions related to these assumptions (Frijns, et al., 2008). Financial experts began to realize that financial decision making, especially investment, does not always depart from rationality.

(Chandra, 2009) has conducted research on the competence of an investor to conduct investors' trades in the stock market. The results obtained from this study indicate that investors who feel more competent trade more often. In addition to investor competence, overconfidence also plays a role in investor trading behavior. The competency factor is one of the psychological factors examined by (Chandra, 2009), which explains that investors with high levels of competence will more often trade stocks. An investor's competence is more influenced by the education and income levels of the investor. The results of (Chandra, 2009) prove that investors who feel capable often carry out trading.

Investors can turn into overconfidence of competence at a later time (Ritter, 2003) Excessive confidence can cause investors to trade excessively, which makes the portfolio returns low. (Graham, Harvey, \& Rajgopal, 2005) conclude that the differences in investors' demographic factors cause investors to feel more competent in understanding financial information and opportunities that are there. The results of his research found that male investors, investors with high incomes, and who have a higher education have more confidence that they are investors with good competence. (Barber \& Odean, 2001) explain that sex is a variable that affects excess confidence in investors. Departing from the above background, the question that will be answered in this study is how the influence of competence and overconfidence on investment decisions on novice stock investors.

\section{Formulation of the Problem}

Based on the background of the problem outlined above, the research questions as follow:

1. Does competence affect investment decisions

2. Does overconfidence affect investment decisions

\section{Research Purposes}

1. To find out and analyze the effects of competence on novice stock investors' investment decisions

2. To find out and analyze the effects of overconfidence on novice stock investors' investment decisions 


\section{LITERATURE REVIEW}

(Heath \& Tversky, 1991) explain that people's willingness to act on their own judgment in a particular area will depend on their subjective competencies i.e. they feel skilled or have knowledge in the context of areas in the capital market, individual competencies of investors perceived in understanding financial information and investment opportunities will affect their willingness to make investment decisions.

\section{Overconfidence}

Overconfidence means conditions in which an individual's confidence in his ability to face an increasingly challenging environment and excessive belief in decisions or opinions without thinking about any conditions that could have happened outside our will. An investor who is very confident in predicting the price of an item, but in reality, the price is different from what was predicted.

\section{Investment Decision}

At the moment, investors are likely to feel competent, and then the investors would be more frequent stock trades that eventually led to higher transaction frequency. (Chandra, 2009) suggests that investors with a high level of competence will often trade shares. Investors can become overconfidence of their abilities, knowledge, and possibilities in the future (Ritter, 2003) Excessive self-confidence can lead investors to trade exaggerated, which makes the return portfolio acquired becomes lower (Graham, Harvey, \& Huang, 2009)

\section{Prior Research}

There are some researches that are references for the current research, namely:

1) (Andrew \& Linawati, 2014)

A study entitled "The Relationship between Demographic Factors and Financial Knowledge with Financial Behavior of Private Employees in Surabaya" was conducted by Vincentius Andrew and Nanik Linawati (2014) and it was published in The Finesta Journal. The data used are primary data obtained through questionnaires. The results conclude that there is a relationship between demographic factors, especially gender, income, financial knowledge, and financial behavior of employees.

2) (Rowley, Shipilov, \& Greve, 2017)

A study entitled "Motivating Women to Adopt Positive Financial Behaviors" was written by Rowley et al. (2012) and published in The Journal of Financial Counseling and Planning. The data used are primary data obtained through questionnaires. The study aimed to identify women's motivations for positive financial behavior changes. The samples of this study were seventeen women aged 25-55 years in America. The data analysis technique used was QSR International. The results of this study conclude that emotional factors, family influence, and life transition help women move from the initial stage to the stage of change.

3) (Ida \& Dwinta, 2010)

A study titled "The Effects of Locus of Control, Financial Knowledge, and Income on Financial Management Behavior" concludes that locus of control and income have no effects on one's financial management behaviors while competence (financial knowledge) affects their financial behaviors. 


\section{RESEARCH METHODS}

This research is descriptive quantitative research and explanatory research that describes the relationship between one variable to another variable.

\section{Research Location and Time}

The researchers distributed questionnaires to the customers of PT Reliance Sekuritas Indonesia, Tbk, and it was held from February to July 2019.

\section{Population and Sample}

The population in this study is the novice shares investor of an investment company in Tasikmalaya, namely PT Reliance Sekuritas, Tbk. The samples consist of 30 people. The novice investors were defined as investors with time to participate in stock investment under 1 year.

\section{Data Types and Sources}

The types of data in this study are divided into two parts, namely:

a. Primary Data

The data on competence, overconfidence, and investment decisions were obtained through interviews and questionnaires.

b. Secondary Data

Secondary data are the data collected from other parties, existing or available data which are then reprocessed for specific purposes. This data are in the form of history and circumstances, literature, articles, and scientific writings that are considered relevant to the topics of competence, overconfidence, and investment decisions. The data collection techniques used in this study consisted of:

1) Field Research

Field research is conducted directly on the object of research so that it can be known the actual conditions in the following ways:

a. Interviews, namely activities collection of data and facts in a way to conduct interviews directly to the respondents regarding the investment decisions.

b. The questionnaire, which is to distribute questions about related problems to selected respondents to find out their responses regarding competence, overconfidence, and investment decisions.

2) Research Library

Literature research is a method of collecting data which is done by studying the literature relating to competence, overconfidence, and investment decisions so that it can be used as a basis for analysis.

\section{Conceptual Definitions and Operational Definitions}

The variables in this study were divided into two types, namely:

1. The independent variable $(\mathrm{X})$, the variable that affects the dependent variable. The independent variables in this study are competence (X1) and overconfidence (X2)

2. The dependent variable (Y), the variable that is influenced by the independent variable. The dependent variable in this study is the investment decision. 
Table 1. Operationalization of Variables

\begin{tabular}{|c|c|c|c|}
\hline Variables & $\begin{array}{c}\text { Operational } \\
\text { Definition }\end{array}$ & Indicator & Scale \\
\hline (1) & (2) & (3) & (4) \\
\hline $\begin{array}{c}\text { Investor Competence } \\
\text { (X1) }\end{array}$ & $\begin{array}{l}\text { Subjective skills or } \\
\text { level of knowledge }\end{array}$ & $\begin{array}{ll}\text { 1. } & \text { Skills } \\
\text { 2. } & \text { Knowledge } \\
\text { 3. } & \text { Nature } \\
\text { 4. } & \text { Motivation } \\
& \text { (Motive) } \\
\end{array}$ & Ordinal \\
\hline $\begin{array}{l}\text { Investor Overconfidence } \\
\text { (X2) }\end{array}$ & $\begin{array}{l}\text { Excessive self- } \\
\text { confidence \& one of } \\
\text { the psychological } \\
\text { biases regarding how } \\
\text { well one understands } \\
\text { the abilities, } \\
\text { knowledge and } \\
\text { limitations that } \\
\text { one has }\end{array}$ & $\begin{array}{ll}\text { 1. } & \text { Self-concept } \\
\text { 2. } & \text { Risk tolerance } \\
\text { 3. } & \text { Investment } \\
& \text { strategy }\end{array}$ & Ordinal \\
\hline $\begin{array}{l}\text { Investment Decision } \\
\text { (Y) }\end{array}$ & $\begin{array}{l}\text { All managerial } \\
\text { decisions that allocate } \\
\text { funds to various } \\
\text { types of assets related } \\
\text { to shares buying and } \\
\text { selling activities and } \\
\text { actions } \\
\text { which is based on } \\
\text { estimates made } \\
\text { previously }\end{array}$ & $\begin{array}{ll}\text { 1. } & \text { Loss of experience } \\
\text { 2. } & \text { Stock information } \\
\text { 3. } & \text { Investment quality } \\
\text { 4. } & \text { Investment } \\
\text { 5. } & \text { productivity } \\
\text { Market } & \text { expectations } \\
\text { 6. } & \text { Market corrections } \\
\text { 7. } & \text { Trading level of } \\
& \text { stock volume } \\
\text { 8. } & \text { Stock return rate } \\
\end{array}$ & Ordinal \\
\hline
\end{tabular}

\section{Variable Measurement Scale}

The main instruments used for data collection were questionnaires, which are a form of statements that have been prepared previously with the aim that the purpose of the statement can be known clearly, with a combination of multiple choices containing a set of respondents' statements regarding an attitude object. Each type of respondent was assessed using an attitude scale guided by the Likert scale. The attitudes of these statements show either positive or negative opinions. Each type of respondent was assessed according to the direction of the statement, namely:

a. For positive statements, the value scale used is 5-4-3-2-1.

b. For negative statements, the value scale used is 1-2-3-4-5.

\section{Research Paradigm}

To further explain the effect of financial literacy on financial behavior, the following paradigm is made: 


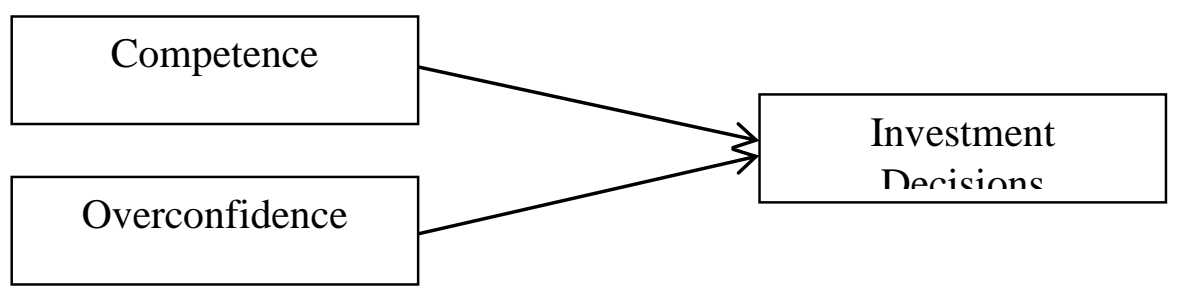

Figure 1 . Research Paradigm

\section{Analytical Tool}

The analytical tool used in this study was a multiple regression analysis. The regression analysis is a linear regression model involving more than one independent variable.

\section{RESULTS AND DISCUSSION}

\section{Characteristics of Respondents}

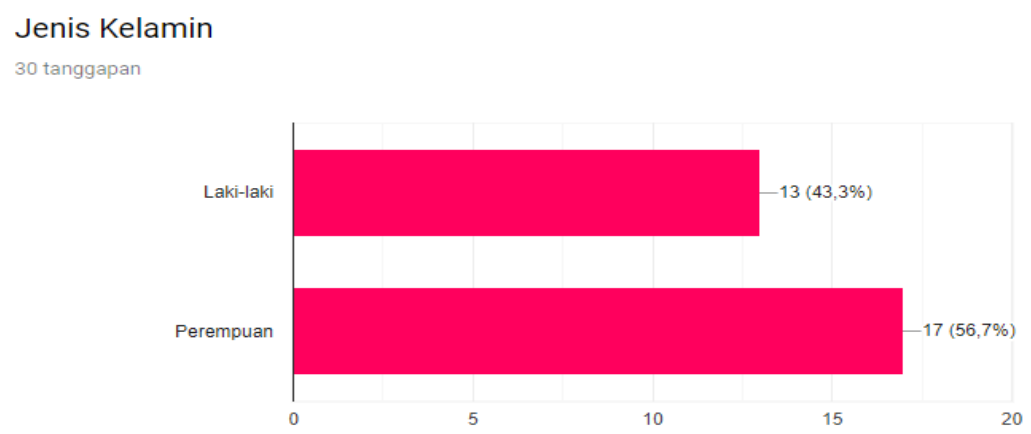

\section{Hypothesis Testing}

Pendidikan Terakhir

30 tanggapan

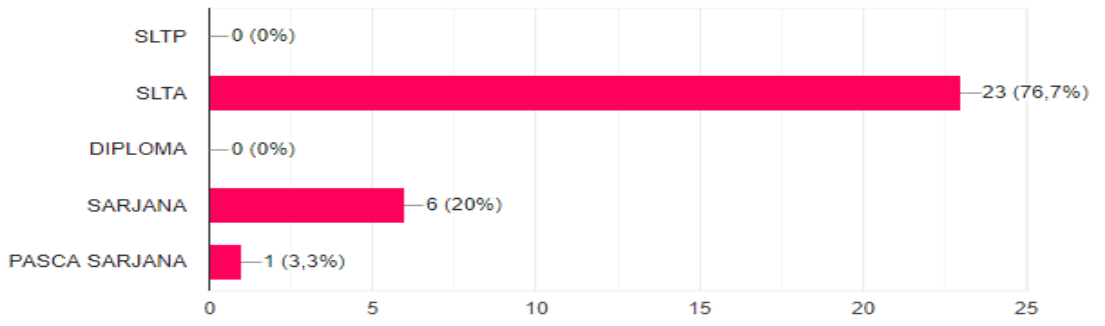


The following is a summary of the results of hypothesis testing using multiple regression to test the effects of competence and overconfidence on investment decisions.

Table 2 shows a summary of the results of the regression test in which the value shown in the table is the regression coefficient (ß), $\mathbf{t}$ arithmetic, and significance value for each relationship between variables.

Table 2. Summary of the Results of the Influences of Competence and Overconfidence on Investment Decisions

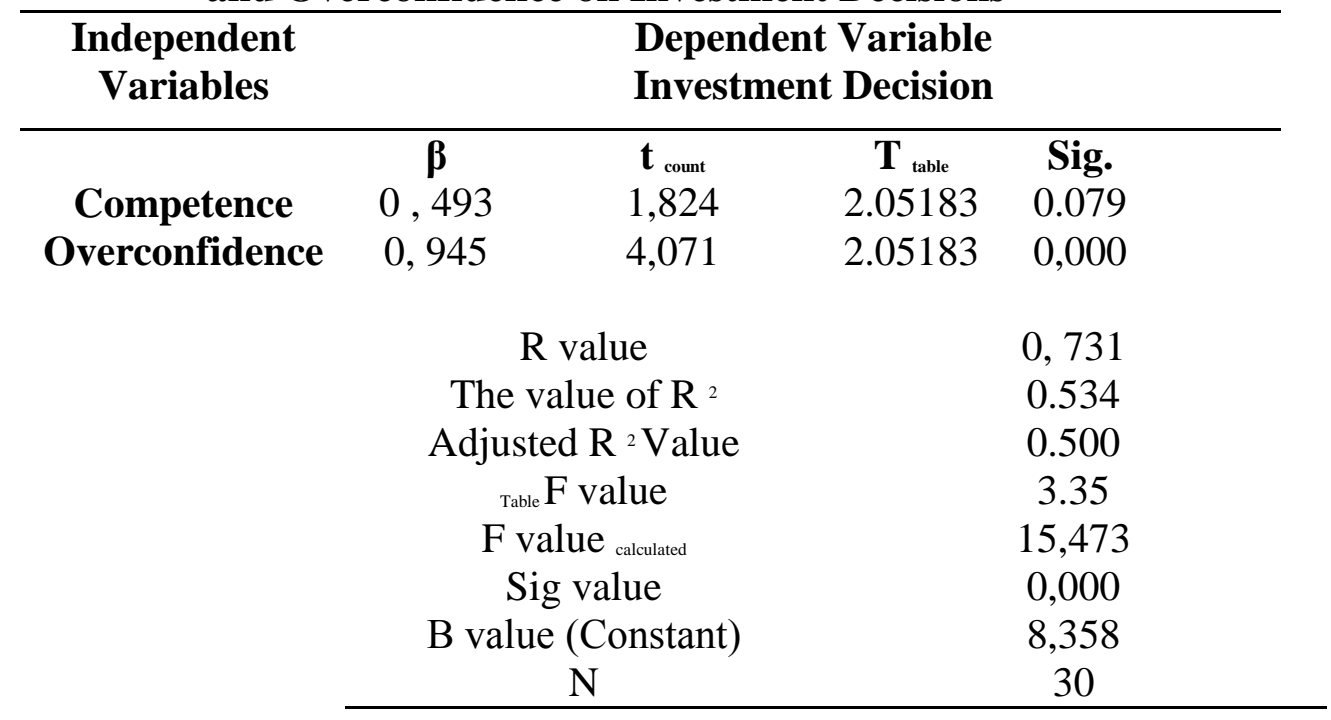

\section{Discussion}

From the table above, $t$-test for competence is $1,824<\mathrm{t}$ table 2.05183 and with a significance level of 0.079 . It means that the probability of significance is above 0.05. That is, the competence of novice investors do not affect investment decisions. This indicates a person is not affected by the competency in making an investment decision. The respondents with low competence can make investment decisions according to the chosen risk profile. Thus, to invest does not require someone to be competent first. Due to many factors that influence an investor in making an investment other than competence, one of them is overconfidence which the researchers chose as the second independent variable.

From the above table, $\mathrm{t}$ - counts for overconfidence of $4.071>\mathrm{t}$ - table of 2.05183 and a significance level of 0.000 indicate that the probability of significance is below 0.05 . It means overconfidence affects investment decisions. Confidence levels affect investors in making investment decisions. An investor who has excessive self-confidence in investment decision making will make decisions according to his level of confidence, not considering the news or information available. Investors who have excessive confidence (overconfidence) assume that the decisions taken will increase return, not paying attention to the risks. This makes the risk obtained by investors who overconfidence is higher than investors who do not have excessive confidence. 


\section{CONCLUSION}

Based on the results described above, the following conclusions can be drawn:

Competence does not affect investment decision making. Seen from t-count, it shows that competency is $1.824>\mathrm{t}$ table 2.05183, and 0.079 significance level it shows that probability significance above 0.05 . It means for a novice stock investor. Investment decisions are not always based on the level of competency possessed. This can be caused by decision making in investment influenced by various things and requires mastery of certain competencies. However, the level of competence that is still low will not hinder decision making because alternative investments can be narrowed by involving other parties deemed more competent, for example, recommendations from analysts or stockbrokers. This can be used as an alternative to reduce the risk of existing competency gaps.

On the other hand, overconfidence affects investment decisions. This can be seen from the t-count of overconfidence is 4,071>t - table2,018183, and the significance level of 0,000 shows that the probability of significance is below 0.05 . Usually, novice stock investors have a high level of enthusiasm for investing. This can be driven by curiosity and high optimism. In addition, they have the readiness to accept relatively high risks, as well. A low level of competence is covered by a high level of trust in the selected recommendation giver, making them more courageous to make investment decisions.

\section{REFERENCE}

Andrew, V., \& Linawati, N. (2014). Hubungan Faktor Demografi dan Pengetahuan Keuangan Dengan Perilaku Keuangan Karyawan Swasta di Surabaya. Finesta.

Barber, B. M., \& Odean, T. (2001). Boys will be boys: Gender, overconfidence, and common stock investment. Quarterly Journal of Economics. https://doi.org/10.1162/003355301556400

Chandra, A. (2009). Individual Investors' Trading Behavior and the Competence Effect. The Icfai University Journal of Behavioral Finance.

Graham, J. R., Harvey, C. R., \& Huang, H. (2009). Investor competence, trading frequency, and home bias. Management Science. https://doi.org/10.1287/mnsc.1090.1009

Graham, J. R., Harvey, C. R., \& Rajgopal, S. (2005). The economic implications of corporate financial reporting. Journal of Accounting and Economics. https://doi.org/10.1016/j.jacceco.2005.01.002

Gumanti, T. A. (2009). Teori Sinyal Manajemen Keuangan. Manajemen Dan Usahawan Indonesia.

Heath, C., \& Tversky, A. (1991). Preference and belief: Ambiguity and competence in choice under uncertainty. Journal of Risk and Uncertainty. https://doi.org/10.1007/BF00057884

Ida, \& Dwinta, C. Y. (2010). Pengaruh Locus of Control, Financial Knowledge, Income Terhadap Financial Management Behavior. Jurnal Bisnis Dan Akuntansi.

Nofsinger, J. R. (2005). Social Mood and Financial Economics. Journal of Behavioral Finance. https://doi.org/10.1207/s15427579jpfm0603_4 
Deasy Lestary Kusnandar ${ }^{1)}$, Agi Rosyadi ${ }^{2)}$,Lucky Radi Rinandiyana ${ }^{3}$ ), Share Investors' Competence and Overconfidence in Investment Decision Making

Ritter, J. R. (2003). Behavioral finance. Pacific Basin Finance Journal. https://doi.org/10.1016/S0927-538X(03)00048-9

Rowley, T. J., Shipilov, A. V., \& Greve, H. R. (2017). Board reform versus profits: The impact of ratings on the adoption of governance practices. Strategic Management Journal. https://doi.org/10.1002/smj.2545 